Al-Manhaj: Journal of Indonesian Islamic Family Law, 2 (1), 2020: 18-30

ISSN: 2715-003; E-ISSN 2714-5514

DOI: http://dx.doi.org/10.19105/al-manhaj.v2i1.3419

\title{
Peran Kyai Dalam Mediasi Untuk Penyelesaian Konflik Pasca Pernikahan Dini di Madura
}

\author{
Syaiful Bahri \\ (Pascasarjana Institut Agama Islam Negeri (IAIN) Madura, \\ bsyaifulbahri62@gmail.com)
}

\begin{abstract}
Abstrak:
Islam menganjurkan untuk upaya saling (ishlah) damai apabila terjadi persengketaan dengan mendatangkan perantara (hakam) atau mediator manakala terjadi persengketaan di dalam rumah tangga.

Mediasi tidak hanya dilakukan secara integral di Pengadilan Agama, Mahkamah Agung dapat membuka pintu mediasi di luar Peradilan Agama melalui optimalisasi peran BP4 dan mendirikan lembaga-lembaga mediasi yang terakreditasi oleh Mahkamah Agung. Perguruan Tinggi Agama Islam khususnya Fakultas Syari'ah dan Hukum dapat ditunjuk sebagai lembaga yang kompeten menangani mediasi, baik mediator maupun lembaga penyelenggara pelatihan. Lembaga mediasi dapat pula berdiri di Pesantren-pesantren. Para ulama dan kyai dapat berperan sebagai mediator bagi para pihak yang memilik sengketa keperdataan. Keterlibatan ulama dan kyai menjadi mediator didasarkan atas pendapat para ulama tafsir yang mensyaratkan bahwa seorang juru damai (mediator) memiliki beberapa syarat, diantaranya Khauf, Taqwa, Faqih dan juga faham terhadap masalah yang sedang disengketakan. Para kyai dan ulama adalah sosok yang dipandang memiliki kualifikasi tersebut dan kharisma yang mampu bisa mempengaruhi para pihak yang bertikai.

Keberadaan seorang kyai bisa menjadi perantara untuk mendamaikan pihak-pihak yang bersengketa sejalan dengan
\end{abstract}


Status Hukum Anak Sah dan Tidak Sah Pra Putusan MK Nomor 46/PUU-VIII/2010

ajaran Islam, dengan mengadukan masalah kepada kyai. Selain itu permusuhan kedua belah pihak menjadi lebih berkurang. Hal ini lebih baik dan ringan daripada perkara sampai ke Pengadilan dan diputus dengan suatu putusan, karena biasanya pihak tergugat dikalahkan didalam pelaksanaan putusan yang harus dilaksanakan secara terpaksa. ${ }^{1}$

Kata Kunci;

Kyai, Mediasi, Pernikahan Dini, Madura

\section{Pendahuluan}

Pernikahan merupakan ikatan lahir batin yang kuat dan kekal antara dua insan, rasa cinta kasih, kewajiban, dan untuk meneruskan keturunan bagi umat Islam. Salah satu tujuan syari'at Islam adalah memelihara kelangsungan keturunan, maka Allah akan memberikan wadah untuk merealisasikan keinginan tersebut sesuai dengan syari'at Islam yaitu melalui pernikahan, yang sah menurut agama, diakui oleh Undang-undang dan diterima sebagai bagian dari budaya masyarakat. ${ }^{2}$ Oleh karena itu, pernikahan yang dilakukan oleh setiap masyarakat harus sesuai dengan ketentuan peraturan perundangundangan dan tidak boleh menyalahi ketentuan hukum agama maupun hukum negara. ${ }^{3}$

Menikah pada usia muda (dini) menurut sebagian masyarakat di Madura merupakan hal perbuatan yang biasa, bahkan menjadi budata baru yangharus dijaga dan dilestarikan, karena kebiasaan tersebut merupakan kebiasaan dari nenek moyang yang diwarisi secara turun temurun. Mayoritas para kyai dan tokoh masyarakat

\footnotetext{
${ }^{1}$ Retno Wulan Sutantio dan Iskandar Cer Kertawinarta, Hukum Acara Perdata Dalam Teori dan Praktek, (Bandung: Mandar Maju, 1997), hlm.35.

${ }^{2}$ Wasman Wardah Nuroniyah, Hukum Perkawinan Islam diIndonesia, (Yogyakarta: Teras, 2011), hlm. 29.

${ }^{3}$ Fuaddudin, Pengasuhan Anak Dalam Keluarga Islam, (Jakarta: Lembaga Kajian Agama dan Jender, 1999), hlm. 4.
} 
membolehkan seseorang menikah pada usia dini dengan catatan sudah mencapai usia baligh meskipun keduanya masih dibawah umur.

Pada umumnya anak yang sudah dianggap (masuk) dewasa untuk menikah ialah setelah anak sudah berusia di atas 18 tahun bagi perempuan, dan 20 tahun bagi laki-laki. ${ }^{4}$ Namun menurut Undangundang perkawinan yang berlaku, batas usia dewasa seorang anak adalah untuk laki-laki 19 tahun dan untuk perempuan 16 tahun. ${ }^{5}$ Jika seorang anak belum mencapai usia yang sudah ditentukan untuk menikah, maka harus memperoleh izin dari orang tua atau wali yang diwujudkan dalam bentuk surat izin sebagai salah satu syarat untuk bisa melangsungkan pernikahan. Bahkan bagi calon yang usianya di bawah 16 tahun harus memperoleh dispensasi nikah dari pengadilan. ${ }^{6}$

Kyai merupakan status yang dihormati dengan seperangkat peran yang dimainkannya dalam masyarakat. Sebagai akibat dari status dan peran yang disandangnya, ketokohan dan kepemimpinan Kyai telah menunjukkan betapa kuatnya kecakapan dan pancaran kepribadian dalam memimpin pesantren dan masyarakat. Hal ini dapat dilihat dari bagaimana seorang kyai membangun peran strategis sebagai pemimpin masyarakat non-formal melalui komunikasi intensif dengan masyarakat. Posisi dirinya di lingkungan Mayarakat pedesaan sama sekali bukan hal baru. ${ }^{7}$

Pencitraan masyarakat Madura sebagai komunitas yang sangat memperhatikan nilai-nilai keagamaan dapat digunakan

\footnotetext{
${ }^{4}$ Abu Al-Ghifar, Badai Rumah Tangga, (Bandung: Mujahid Press, 2003), hlm. 132.

${ }^{5}$ Undang-undang Nomor. 1 Tahun 1974 Tentang Perkawinan. Pasal 7 ayat (1).

${ }^{6}$ Zuhdi Muhdlor, Memahami Hukum Perkawinan, (Bandung: Al-Bayani), hlm. 1819.

${ }^{7}$ Manfred Ziemek, Pesantren dalam Perubahan Sosial (Jakarta: P3M., 1986), hlm. 138.
} 
Status Hukum Anak Sah dan Tidak Sah Pra Putusan MK Nomor 46/PUU-VIII/2010

sebagai "pintu masuk" dalam mengkaji kepemimpinan seorang Kyai dengan bertitik tolak dari teori proses Islamisasi di Madura. ${ }^{8}$

\section{Kajian Terdahulu:}

1. Muhammad Yusuf, Pandangan Hukum Islam Terhadap Penikahan Dini di Pengadilan Agama Mungkid (Studi Kasus Perkara No. 0065/Pdt.P/2009/PA.Mkd). Skripsi S1 Program Studi Al-Ahwal Asy-Syari'ah Universitas Islam Negeri Sunan Kalijaga, (Yogyakarta: 2010). Didalam kajian pertama ini menjelaskan tentang pandangan hukum Islam dan menjelaskan jumlah angka Pernikahan Dini di Pengadilan tersebut.

2. Hairi, Pernikahan Dini di Kalangan Masyarakat Madura (Studi Kasus di Desa Bajur Kecamatan Waru Kabupaten Pamekasan), Skripsi S1 Program Studi Sosioogi Agama Fakultas Ushuluddin Universitas Islam Negeri Sunan Kalijaga, (Yogyakarta: 2009). Dan didalam kajian yang kedua ini menjelaskan banyaknya Masyarakat yang menikah di Usia Dini.

\section{Pembahasan:}

\section{A. Kedudukan Kyai dalam Masyarakat Madura}

Secara umum, ahli-ahli pengetahuan keagamaan Islam disebut Ulama. Dalam perspektif lokal, di Jawa Barat mereka (kyai) disebut Ajengan, di Jawa Tengah dan di Jawa Timur disebut dengan Kyai. Sebutan kyai merupakan gelar kehormatanyang diberikan oleh masyarakat kepada seorang ahli Agama Islam yang memiliki atau menjadi pemimpin daripada Pondok Pesantren dan mengajarkan kitab-kitab Islam klasik kepada santrinya. Selain daripada gelar kyai, ia sering disebut orang Alim, dalam artian seseorang yang mendalami ilmu keagamaan. Mengingat kaitan yang sangat kuat dengan tradisi

\footnotetext{
${ }^{8}$ Abdur Rozaki, Menabur Kharisma Menuai Kuasa: Kiprah Kiai dan Blater sebagai Rezim Kembar di Madura. Yogyakarta: Pustaka Marwa, 2003), hlm. 1.
} 
pesantren, gelar kyai biasanya dipakai untuk menunjuk para ulama dari kelompok Islam tradisional. ${ }^{9}$

Meskipun kebanyakan kiai di Jawa tinggal di pedesaan, mereka merupakan bagian dari kelompok elit dalam struktur sosial politik dan ekonomi masyarakat Jawa, merupakan kekuatan penting dalam kehidupan politik Indonesia. Mereka adalah pengajar dan pemimpin, yang memiliki kedudukan tinggi di masyarakat, dan untuk menjalankan tugasnya sebagai pengajar Islam dengan baik, mereka perlu memahami kehidupan politik. Mereka dianggap dan menganggap diri memiliki suatu posisi yang mempunyai kedudukan yang menonjol dalam tingkat lokal maupun nasional. Dengan demikian mereka merupakan pembuat keputusan yang efektif dalam kehidupan sosial orang Jawa, tidak hanya dalam kehidupan keagamaan tetapi juga dalam sosial politik. Profesi mereka sebagai pengajar dan penganjur Islam membuahkan pengaruh yang melampaui batas-batas desa (bahkan kabupaten)dimana pesantren mereka berada. 10

Di Madura, sebutan untuk ulama atau kiai seperti diatas adalah Kyaeh. Seorang kiai biasanya memiliki atau memimpin sebuah pondok pesantren. Tetapi, dapat juga karena ia memiliki darah keturunan seorang kiai. Sampai saat ini, unsur keturunan-keturunan itu merupakan faktor penentu penyebutan seorang sebagai kiai. Apalagi jika faktor keturunan tersebut berkaitan dengan kiai yang karismatik, maka anak-anaknya secara otomatis juga akan disebut kiai oleh masyarakat Madura. Ia akan mudah mempengaruhi dan menggerakkan masyarakatnya. ${ }^{11}$

\footnotetext{
${ }^{9}$ Zamakhsyari Dhofier, Tradisi Pesantren. (Jakarta: LP3ES, 2011), hlm. 93.

${ }^{10}$ Zamakhsyari Dhofier, Tradisi Pesantren: Studi tentang Pandangan Hidup Kyai. (Jakarta: LP3ES, 1982), hlm. 56.

${ }^{11}$ Andang Subaharianto dkk, Tantangan Industrialisasi Madura, Membentur Kultur, Menjunjung Leluhur, (Malang: Banyumedia Publishing, 2002) hlm.52-53.
} 
Status Hukum Anak Sah dan Tidak Sah Pra Putusan MK Nomor 46/PUU-VIII/2010

Sedangkan dalam bahasa Madura Kyai disebut juga dengan panggilan Kyaeh, Ma'kaeh. Mereka akan menjadi panutan masyarakat dalam berbagai hal yang menyangkut kehidupan sehari-hari. Ma'kaeh juga merangkap sebagai penghulu atau juru nikah, kapasitas dirinya tidak ada bedanya seperti modhin yang setiap saat selalu siap ketika dibutuhkan dalam proses pernikahan, termasuk pernikahan dini. ${ }^{12}$

Ulama atau Kyaeh memiliki tempat yang spesifik dalam masyarakat Madura, tidak hanya karena proses historis seperti diatas, tetapi juga didukung oleh kondisi-kondisi ekologi dan struktur pemukiman penduduk yang ada. Kondisi-kondisi demikian yang kemudian melahirkan organisasi sosial yang tertumpu pada agama dan otoritas ulama. Ulama merupakan perekat solidaritas dan kagiatan ritual keagamaan, pembangunan sentimen kolektif keagamaan, dan penyatu elemen-elemen sosial atau kelompok kekerabatan yang tersebar karena faktor-faktor ekologis dan struktur pemukiman tersebut. Oleh karena itu,bukan hal yang berlebihan jika ulama atau kiai sebagai pemegang otoritas keagamaan memiliki pengaruh yang besar dalam kehidupan orang Madura. ${ }^{13}$

Kajian tentang kedudukan Kyai dalam Masyarakat Madura mesti mengikutsertakan dimensi kepemimpinan. Karena keduanya adalah bagian integral yang tidak dapat dipisahkan dan mengandung status dan peran yang dimainkan sekaligus predikat yang disandangnya dalam Masyarakat. Kyai merupakan sosok pribadi yang akan ditiru oleh Masyarakat baik dari segi perkataan, tindakan dan hal-hal lainnya yang bersifat positif (baik), setiap persoalan yang terjadi di Masyarakat baik dari segi Duniawi dan Ukhrawi dan sering diminta kehadirannya untuk menyelesaikan problem yang menimpa

\footnotetext{
${ }^{12}$ Suyono, Kredibilitas Pemuka Pendapat Dalam Tradisi Pernikahan Dini di Madura, Jurnal Imu Komunikasi MEDIAKOM Vol . 01 No. 02 Tahun 2018, hlm. 200.

${ }^{13}$ Ibid. Hlm. 53-54.
} 
masyarakat kebanyakan titik jalan keluarnya ada pada diri Kyai, karena Kyai merupakan Publik Figur daripada Masyarakat tersebut.

Kepemimpinan Kyai, sering diidentikkan dengan atribut kepemimpinan kharismatik. Dalam konteks tersebut, Sartono Kartodirjo menyatakan bahwa kyai-kyai pondok pesantren, baik dulu maupun sekarang, merupakan sosok penting yang dapat membentuk kehidupan sosial, kultural dan keagamaan warga muslim di Indonesia. ${ }^{14}$ Pengaruh Kyai terhadap kehidupan Masyarakat atau santri tidak terbatas akan tetapi berlaku dalam kurun waktu panjang, bahkan sepanjang hidupnya, ketika sudah terjun di tengah-tengah masyarakat.

\section{B. Konflik Pasca Pernikahan Dini di Madura}

Didalam penulisan ini, pelaku Pernikahan di Usia Dini di Madura dampak yang dirasakan oleh pasangan yang melakuan pernikahan dini itu sendiri. Diantaranya:

a. Sering terjadi pertengkaran yang disebabkan pembagian kerja kurang adil. Seperti halnya pihak suami mengabaikan tugasnya untuk mencari nafkah, ataupun pihak istri yang malas melakukan tugasnya sebagai ibi rumah tangga.

b. Hamil usia muda dan keguguran, jika tidak keguguran bayi yang keluar premature.

c. Perekonomian mengalami kekurangan dan sebagian besar masih menumpang pada orang tua ataupun mertua.

\section{Dampak Positif}

Dampak positif daripada Penikahan Dini di Madura diantaranya:

a. Dapat meringankan beban kedua belah pihak, nantinya dengan adanya (terjadi) pernikahan dini anak mereka hidup dan kehidupan mereka untuk selanjutnya akan lebih baik daripada orang tuanya, khususnya bagi pihak perempuan.

\footnotetext{
${ }^{14}$ Sartono Kartodirjo, Religious Movement of Java in the 19th and 20th Centuries. (Yogyakarta: Gajah Mada University, 1970), hlm. 114.
} 
Status Hukum Anak Sah dan Tidak Sah Pra Putusan MK Nomor 46/PUU-VIII/2010

b. Terhindar (bebas) dari gunjingan masyarakat, karena anaknya tidak termasuk perawan atau perjaka tua, karena asumsi mereka jika semakin tua menikahkan anaknya maka akan semakin banyak juga gunjingan dari masyarakat.

c. Menghindari para pemuda dan pemudi dari hal negatif (penyimpangan).

d. Belajar memikul daripada tanggung jawab di usia muda, disini mereka harus dapat mengatur urusan-urusan mereka tanpa bergantung kepada kepada orang tuanya. ${ }^{15}$

\section{Dampak Negatif}

Dampak negatif daripada Pernikahan Dini banyak berdampak pada pelaku, orang tua dan pada anak yang akan dilahirkan, diantaranya:

a. Pendidikan. Seorang yang melakukan pernikahan usia dini tentu akan membawa bermacam dampak, terutama didalam dunia pendidikan yang rentan dengan keberlangsungan ekonomi. Seorang yang melangsungkan pernikahan usia dini kebanyakan baru lulus dari SD/MI atau SMP/MTS tentu dalam keinginan untuk menempuh pendidikan yang lebih tinggi lagi tidak tercapai.

b. Kelangsungan Rumah Tangga. Tidak tercapainya tujuan pernikahan yang membentuk keluarga Sakinah, Mawaddah dan Rahmah. Hal ini disebabkan sering terjadi pertengkaran kedua belah pihak karena tidak bisa menahan emosi dari masingmasing yang belum matang.

c. Kesehatan. Perempuan yang menikah di usia muda kurang dari 15 tahun maka akan banyak memiliki resiko, sekalipun ia pernah mengalami menstruasi. Ada dua dampak yang akan ditimbulkan dari pernikahan dini, yakni dampak dari

${ }^{15}$ Titi Nur Indah Sari, Skripsi: Fenomena Pernikahan Usia Muda di Masyarakat Madura "Studi Kasus di Desa Serabi Barat Kecamatan Modung Kabupaten Bangkalan" (Jakarta: UIN Syarif Hidayatullah, 2016), hlm. 99-100. 
kandungan yang banyak di derita wanita yang menikah di usia muda, antara lain infeksi kandungan dan kangker rahim. Selain itu juga wanita yang hamil di bawah usia 19 tahun dapat beresiko terhadap kematian, wanita yang hamil di usia yang tidak sampai juga dapat beresiko terhadap pendarahan, keguguran dan di masa kehamilannya hamil prematur. ${ }^{16}$

Masalah-masalah hukum yang timbul dari pernikahan dini harus segera diatasi, salah satunya adalah dengan pembentukan Kelompok Masyarakat Sadar Hukum (Kadarkum). Kadarkum bekerjasama dengan Posbakum yang ada untuk secara bertahap untuk menyelesaikan permasalahan. Berdasarkan Undang-undang No. 16 Tahun 2011 tentang Bantuan Hukum Pasal 1 dinyatakan bahwa Bantuan Hukum secara Cuma-Cuma (prodeo) kepada Penerima Bantuan Hukum. ${ }^{17}$

\section{Peran Kyai dalam Menyelesaikan Konflik}

Tahap selanjutanya Kyai mendamaikan para pihak suami istri dengan maksud dan tujuan supaya mereka tidak jadi bercerai. Disini adanya peran kyai sebagai juru damai (hakam) untuk menyatukan lagi dalam rumah tangga kedua belah pihak yang retak tersebut. tindakan kyai sejalan dengan perintah agama merujuk kepada QS. An-Nisa' ayat 35:

وان خفتم شقاق بينهما فابعثوا حكما من اهله وحكما من اهلها. ان يريدآ اصلاحا بينهما، ان الله كان عليما خبيرا. Dan jika kamu khawatirkan ada persenketaan antara keduanya, maka kirimlah seorang hakam dari keluarga laki-laki dan seorang hakam dari

\footnotetext{
${ }^{16}$ Ibid, hlm. 100-102.

${ }^{17}$ Suhadi, dkk, Pencegahan Meningkatnya Angka Pernikahan Dini dengan Inisiasi Pembentukan Kadarkum di Dusun Cemanggal Desa Munding Kecamatan Bergas, Jurnal Pengabdian Hukum Indonesia, (Indonesian Journal of Legal Community Engagement) JPHI, 01 (1) (2018): 31-40, hlm. 32.
} 
Status Hukum Anak Sah dan Tidak Sah Pra Putusan MK Nomor 46/PUU-VIII/2010

keluarga perempuan.jika kedua orang hakam itu bermaksud mengadakan perbaikan, niscaya Allah memberi taufik (pertolongan) kepada suami-istri itu. Sesungguhnya Allah Maha Mengetahui lagi Maha Mengenal.

Melihat ayat tersebut, jelas sekali aturan Islam dalam mendamaikan suami istri yang berselisih didatangkannya perantara (hakam) untuk mendamaikan kedua pihak tersebut. Dalam hal ini, Sayyid Sabiq dalam bukunya Figh Sunnah menjelaskan bahwa hakam tidak harus dari masing-masing pihak. Jika mereka bukan dari masing-masing pihak boleh juga, menurut beliau pemilihan hakam dari kalangan keluarganya hukumnya Sunnah, denhan alasan bahwa keluarga tersebut lebih bersifat kasih sayang, lebih mengetahui apa yang terjadi dan mengenal keadaan masing-masing. ${ }^{18}$

Kata keluarga mempunyai pengertian yang luas, ia bisa berarti termasuk keluarga dalam batas sempit, seperti rumah tangga, kemudian sanak keluarga dan lalu suku. Namun hal ini bisa meluas hingga menyangkut satu dusunnatau satu daerah.

Dari uraian diatas maka perantara (hakam) tidak harus dari masing-masing suami istri akan tetapi boleh dari pihak selain keluarga kedua suami istri tersebut. sehingga keberadaan kyai didalam mendamaikan suami istri yang sedang berselisih dalam masyarakat dapat dibenarka, karena kyai sebagai imamnya masyarakat, dan juga dianggap orang yang paling tepat dan akrab dengan masyarakat, untuk menjadi tempat solusi untuk mengadu dari segala problematika kehidupan. Selain dari urusan ibadah juga urusan didalam kehidupan sehari-hari termasuk juga permasalahan keluarga.

Syara' (aturan Islam) menentukan syarat-syarat seseorang untuk menjadi hakam diantaranya laki-laki dewasa, berakal sehat dan bersikap adil. ${ }^{19}$ Jika melihat dari Syarat-syarat tersebut tentu kriteria

\footnotetext{
${ }^{18}$ Sayyid Sabiq, Fiqh As-Sunnah Jilid II, (Kairo: Daar Al-Hadist, 2009) , hlm. 12.

${ }^{19}$ Amir Syarifuddin, Hakam Perkawinan di Indonesia, Antara Fiqh Munakahat UU Perkawinan, (Jakarta: Kenacama, 2007), hlm. 197.
} 
ini dapat terpenuhi dari seorang kyai. Kyai sama masyarakat dianggap orang yang memiliki ilmu dalam bidang agama, juga dianggap baik dan sholeh. Masyarakat sangat percaya apa kata kyai dengan istilah sami'na wa atho'na. Sehingga apabila masyarakat memilih kyai untuk jadi hakam itu hal sangat wajar dan pantas.

Melihat metode dan strategi yang dilakukan oleh mediator kyai di Madura sebagai berikut:

a. Kyai memanggil para pihak yang bersengketa

b. Kyai memberikan pencerahan (nasehat) dengan pendekatan secara keagamaan

c. Kyai sifatnya moderat hanya sebagai mediator

d. Apabila kedua belah pihak bersikeras untuk bercerai, selanjutnya akan tetap diajukan ke pengadilan

e. Kyai menasehati dengan dengan menggunakan bahasa kata yang halus yang biasa digunakan sehari-hari

f. Kyai berdoa di akhir mediasi

Kebehasilan yang ditangani oleh kyai di Madura sebagai mediatornya oleh masyarakat maka bisa mendatangkan kemashlahatan (kebaikan), diantaranya: Pertama tidak berperkara ke Pengadilan yang membutuhkan proses yang lama dan biaya tidak sedikit, serta dapat mencegah menumpuknya perkara di Pengadilan. Kedua kedua belah pihak tidak mengeluarkan biaya yang banyak, dan juga datang ke kyai tidak membutuhkan waktu yang lama untuk melakukan ishlah (perdamaian). Ketiga hampir semua orang yang datang kepada kyai yang sebelumnya ingin bercerai tidak jadi (gagal) yang ingin bercerai.

\section{Penutup}

Dari beberapa pernyataan diatas tentang Peran Kyai Dalam Mediasi Untuk Penyelesaian Konflik Pasca Pernikahan Dini Di Madura bisa diambil kesimpulan sebagai berikut: 
Status Hukum Anak Sah dan Tidak Sah Pra Putusan MK Nomor 46/PUU-VIII/2010

a. Kyai menjadi perantara (mediarot) untuk mendamaikan pihakpihak yang bersengketa.

b. seorang juru damai (mediator) memiliki beberapa syarat, diantaranya Khauf, Taqwa, Faqih dan juga faham terhadap masalah yang sedang disengketakan.

c. Keberadaan seorang kyai bisa menjadi perantara untuk mendamaikan pihak-pihak yang bersengketa sejalan dengan ajaran Islam.

d. Dampak Pernikahan Dini sering terjadi pertengkaran, disebabkan pembagian kerja kurang adil.

e. Perekonomian (penghasilan) untuk dijadikan nafkah mengalami kekurangan.

f. Tidak tercapainya tujuan pernikahan yang membentuk keluarga Sakinah, Mawaddah dan Rahmah. Hal ini disebabkan sering terjadi pertengkaran kedua belah pihak karena tidak bisa menahan emosi dari masing-masing yang belum matang.

g. Wanita yang hamil di bawah usia 19 tahun dapat beresiko terhadap kematian.

\section{Daftar Rujukan}

Al-Ghifar, Abu. Badai Rumah Tangga, Bandung: Mujahid Press, 2003.

Dhofier, Zamakhsyari. Tradisi Pesantren. Jakarta: LP3ES, 2011.

Dhofier, Zamakhsyari. Tradisi Pesantren: Studi tentang Pandangan Hidup Kyai. .Jakarta: LP3ES, 1982.

Fuaddudin, Pengasuhan Anak Dalam Keluarga Islam, Jakarta: Lembaga Kajian Agama dan Jender, 19994.

Kartodirjo, Sartono. Religious Movement of Java in the 19th and 20th Centuries. Yogyakarta: Gajah Mada University, 1970.

Muhdlor, Zuhdi .Memahami Hukum Perkawinan, Bandung: Al-Bayani, tt..

Nuroniyah, Wasman Wardah. Hukum Perkawinan Islam diIndonesia, Yogyakarta: Teras, 2011. 
Rozaki, Abdur. Menabur Kharisma Menuai Kuasa: Kiprah Kiai dan Blater sebagai Rezim Kembar di Madura. Yogyakarta: Pustaka Marwa, 2003.

Sabiq, Sayyid, Fiqh As-Sunnah Jilid II, Kairo: Daar Al-Hadist, 2009..

Sari, Titi Nur Indah. Skripsi: Fenomena Pernikahan Usia Muda di Masyarakat Madura "Studi Kasus di Desa Serabi Barat Kecamatan Modung Kabupaten Bangkalan" Jakarta: UIN Syarif Hidayatullah, 2016.

Subaharianto, Andang, dkk, Tantangan Industrialisasi Madura, Membentur Kultur, Menjunjung Leluhur, Malang: Banyumedia Publishing, 2002.

Suhadi, dkk, Pencegahan Meningkatnya Angka Pernikahan Dini dengan Inisiasi Pembentukan Kadarkum di Dusun Cemanggal Desa Munding Kecamatan Bergas, Jurnal Pengabdian Hukum Indonesia, (Indonesian Journal of Legal Community Engagement) JPHI, 01 (1) ,2018

Sutantio, Retno Wulan dan Iskandar Cer Kertawinarta, Hukum Acara Perdata Dalam Teori dan Praktek, Bandung: Mandar Maju, 1997.

Suyono, Kredibilitas Pemuka Pendapat Dalam Tradisi Pernikahan Dini di Madura, Jurnal Imu Komunikasi MEDIAKOM Vol . 01 No. 02 Tahun 2018.

Syarifuddin,Amir. Hakam Perkawinan di Indonesia, Antara Fiqh Munakahat UU Perkawinan, Jakarta: Kenacama, 2007.

Undang-undang Nomor. 1 Tahun 1974 Tentang Perkawinan. Pasal 7 ayat (1).

Ziemek, Manfred. Pesantren dalam Perubahan Sosial ,Jakarta: P3M., 1986. 